\title{
MOLECULAR DOCKING OF SECONDARY METABOLITES FROM Psidium guajava L. AND Piper nigrum L. TO COVID-19 ASSOCIATED RECEPTORS ACE2, SPIKE PROTEIN RBD, AND
} TMPRSS2

\section{A PREPRINT}

\section{Maurice De Jesus, Jokent T. Gaza, Hiyas Junio, and Ricky Nellas}

Email: rbnellas@up.edu.ph

August 26, 2020

\begin{abstract}
The SARS-CoV-2 virus has spread worldwide, affecting millions, and showing no signs of slowing down or stopping. Secondary metabolites have been important sources of medicine for millennia. In this study, the secondary metabolites of Psidium guajava L. and Piper nigrum L. were screened for binding to three key coronavirus disease (COVID-19) associated proteins, namely, the viral spike protein, its target ACE2, and its primer TMPRSS2. Through molecular docking, the compounds isoquercetin, terpinyl acetate, morin-3-O-lyxoside, guineensine and brachyamide A were found to have considerable binding to these three receptors. With almost benign ADME-Tox profiles and energetically favorable binding, the secondary metabolite compounds caryophyllene, terpinyl acetate, morin and morin glycosides may be considered for assays, further development, and clinical investigations.
\end{abstract}

Keywords SARS-CoV-2 · Psidium guajava L. · Piper nigrum L. · ACE2 · spike protein · TMPRSS2

\section{Introduction}

The novel coronavirus SARS-CoV-2, etiologic agent of the pandemic COVID-19, has infected people across continents in just four months after its first detection. Now, eight months since its emergence in Wuhan, China, a total of 215 countries report a combined 817,000 deaths, 15.4 million recoveries, and more than 6 million active infections. ${ }^{[1]}$ COVID-19 is transmitted through droplets and targets the human respiratory system. While its symptoms have been 
characterized, the signs manifest up to a week after exposure on average, and around $80 \%$ of individuals that test positive for COVID-19 will be asymptomatic. ${ }^{[2]}$ It progresses in severity by triggering host defenses to cause excessive inflammatory damage to the lungs.

The SARS-CoV-2 viral particle contains a (+)-single strand 30k nucleotide RNA genome, among other organelles. Structural proteins encoded in the genome include the viral replicase, spike, membrane, envelope and nucleocapsid proteins, and numerous nonstructural proteins. ${ }^{[3]}$ Similar to SARS-CoV, the entry of SARS-CoV-2 into the host cell involves the virus' spike protein to the host's angiotensin converting enzyme 2 (ACE2) receptor. ${ }^{[4,5]}$ However, the affinity of SARS-CoV-2 to the receptor protein is up to 20 times greater than SARS-CoV. Unlike SARS-CoV, the spike protein of SARS-CoV-2 makes use of furin and TMPRSS2, proteases commonly found in epithelial cells lining the respiratory tract. ${ }^{[6]}$ This makes the virus as invasive as influenza, HIV and Ebola viruses. ${ }^{[7,8]}$ SARS-CoV-2 also lessens the expression of type I and type III interferons and instead promotes the production of inflammatory cytokines such as of interleukin 6 (IL-6). ${ }^{[9]}$ This results to the rapid exhaustion of antigen-specific lymphocytes and the recruitment of nonspecific neutrophils, causing damage to both healthy and infected cells. ${ }^{[10]}$ This cytokine storm can ultimately lead to acute respiratory distress syndrome (ARDS). ${ }^{[11,12]}$

The search for COVID-19 treatments commonly involve the viral spike protein, its associated human receptor ACE2, and the human primers of spike protein TMPRSS2, cathepsin B/L, and furin. ${ }^{[13]} \mathrm{A}$ large number of virtual screening studies recognize the importance of inhibiting viral entry by binding ligands on the interface of the primed spike protein receptor binding domain (RBD) and ACE2 structures ${ }^{[14-16]}$. Studies on the inhibition of TMPRSS2 protease also support the discovery of compounds that affect the priming process to limit the recognition of spike RBD to ACE2 receptors. ${ }^{[6]}$ With the availability of these protein structures in databases ${ }^{[17-20]}$, investigations on the potential of repurposed drugs ${ }^{[21]}$, essential oils ${ }^{[22]}$, and ligands available online ${ }^{[23]}$ as treatments for COVID-19 are being initiated. Secondary metabolites have a long history of antiviral activity. ${ }^{[24]}$ Numerous medicines for viral diseases either occur naturally or are derivatives. ${ }^{[25]}$ Plants commonly found in tropical regions have been established as great sources of potential antiviral compounds. Examples of which include guava (Psidium guajava L.) and black pepper (Piper nigrum L.). Among the many documented antiviral effects of guava and black pepper are on the illnesses influenza $\mathrm{A}^{[26-28]}$ and hepatitis $\mathrm{B}^{[29]}$, and nonspecific protection from viral pathogenesis through immunomodulation ${ }^{[30,31]}$.

In this study, secondary metabolites from P. guajava L. and P. nigrum L. were screened for potential binding to proteins that facilitate recognition and priming of SARS-CoV-2. Their docking can provide information on the affinity and binding sites of these compounds to key proteins involved in COVID-19. However, the ultimate curative property of these secondary metabolites against the pandemic is beyond the scope of this study. This research provides to the pool of in silico data. 


\section{Methodology}

A. Secondary metabolites from $P$. guajava L. and $P$. nigrum L.

The screened $P$. guajava L. secondary metabolites were derived from a study by Arima and Danno ${ }^{[32]}$, while those of P. nigrum L. were obtained from the work of Dawid, et. al ${ }^{[33]}$. Docking was performed on the ligands (Figure 1). All of the compounds originating from P. guajava L. are terpenoids, except isoquercetin, morin, and the two morin glycosides, which are flavonoids. All compounds from P. nigrum L. are alkaloids with extensive conjugation. With the exception of piperlongumine and guineensine, the P. nigrum L. alkaloids are either pyrrolidine or piperidine derivatives.

\section{B. Protein preparation}

The structures of human ACE2-SARS-CoV spike protein RBD complex were accessed from the RCSB Protein Data Bank (PDB IDs 2AJF, 3SCI, 6ACK, 6M17). The homology model of TMPRSS2, on the other hand, was retrieved from the SwissModel repository using the code O15393. Single chain ACE2 and spike protein RBD receptors were derived from the RCSB structures.

\section{Docking and ADME-Tox analysis}

The secondary metabolites from $P$. guajava L. and $P$. nigrum L. were docked to the nine prepared receptors using AutoDock Vina ${ }^{[34]}$. The docking search space encloses the entire receptor in a box with $5 \AA$ distance from each side of the structure. To determine all possible interactions between the ligands and receptors, all docking poses and binding energy values were considered in the PLIP ${ }^{[35]}$ analysis. Determination of drug-likeness was done using the SwissADME $^{[36]}$ and ProTox-II webservers ${ }^{[37]}$.

\section{Results}

Based on Table 1, the average docking score for all secondary metabolites from P. guajava L. and P. nigrum L. was around $-6.1 \mathrm{kcal} / \mathrm{mol}$. Among the compounds, morin-3-O-lyxoside had the lowest binding energy average on all receptors. Next to morin and the 2 morin glycosides, the secondary metabolites isoquercetin, piperoleine B and pipernonaline are among the top binding ligands on all receptors. These ligands show better binding affinities than the serine protease inhibitor, camostat. All ligands bind with greater affinity to the ACE2 structures than to the other receptors.

In a previous work ${ }^{[22]}$, the docking of camostat to its putative receptor TMPRSS2 was determined. The interacting residues of camostat were found to be distal from the charge transfer pocket of TMPRSS2. As shown in Figure 2 and listed in Table 2, no interactions were found with the TMPRSS2 charge transfer pocket. ${ }^{[38]}$ Instead, the docked poses 
are all found on the same cleft occupied by camostat. The residues identified in the binding of camostat (Cys148, Ile221, Lys223, and Gly370) are also the common interacting residues for the screened molecules. The compound morin recorded the lowest binding energy value while isoquercetin had the most hydrophobic, hydrogen bonding, and $\pi$-stacking interactions to TMPRSS2 receptor.

There are two druggable sites in the human ACE2 receptor. The first site is a catalytic pocket containing Arg273, His345, His505, the principal catalytic residue Glu375, and the three residues (His374, His378, and Glu402) that hold a zinc cofactor in place ${ }^{[39]}$. The second site consists of residues 19 to 85 (helices $\alpha 1$ and $\alpha 2$ ) and 351 to 357 (residues that connect sheets $\beta 3$ and $\beta 4$ ) which are found in the interface that accommodates the SARS-CoV-2 Spike protein $\mathrm{RBD}^{[4]}$. The interactions of ACE2 and the docked compounds are listed in Table 3 and shown in Figures 3 and 4 . At a glance, it can be seen that the majority of the binding interactions occur at regions away from the two sites. Most of the docking poses are located in the ridge within ACE2. Interestingly, this region, referred to as the central core of the protein, is the site wherein all other sections of the protein fold into as a newly expressed ACE2 polypeptide chain morphs into its active form. This happens in the late intermediate stage of ACE2 folding, and at this point, the preformed ACE2 contains transient druggable sites. ${ }^{[40]}$ Since the P. guajava L. and P. nigrum L. secondary metabolites are located near residues on both the central core and adjacent sections of ACE2, the binding of these compounds to the late intermediate stages of ACE2 folding may warrant investigation.

In general, the binding of secondary metabolites to spike protein receptors yielded less affinity compared to their binding on ACE2 receptors. The interactions with spike protein are recorded in Table 4 and displayed in Figures 5 and 6. Interestingly, the docking poses clustered around one site per receptor. The spike protein structures 2AJF.E and 3SCI.E have interactions with the P. guajava L. and P. nigrum L. secondary metabolites on or near their $\beta 1$ region. These receptors' spike proteins belong to the 2002 SARS-CoV virus. ${ }^{[17,18]}$ On the receptor 6ACK.A, another spike protein RBD from SARS-CoV ${ }^{[19]}$, most of the docking poses are in the vicinity of the loop between $\beta 1$ and $\beta 2$. On receptor 6M17.E, a SARS-CoV-2 RBD structure ${ }^{[20]}$, all of the secondary metabolite compounds docked in this site as well. Isoquercetin, guineensine and brachyamide $\mathrm{A}$, however, were located on the region next to the $\beta 5$ and $\beta 6$ sheets of 6M17.E. ${ }^{[41]}$ Residues in this region are at the interface of the ACE2 complex and either SARS-CoV or SARS$\mathrm{CoV}-2$ spike protein RBD. These three compounds that bind to the interface portion of 6M17.E may be considered for further studies into their effects on complex disruption.

Since the secondary metabolites have generally lower binding energies on the ACE2 receptor versus the respective spike protein receptor (Table 1), most of the docking poses on the ACE2-spike complexes lie on the side of the human peptidase enzyme. Listed in Table 5 and shown in Figures 7 and 8 are the interactions of the P. guajava L. and $P$. nigrum L. secondary metabolites with the complex of spike protein RBD and ACE2. With the exemption of those of terpinyl acetate on 2AJF and caryophyllene on 6M17, all of the interacting residues listed belong to ACE2. Even though caryophyllene has higher affinity towards ACE2 than spike protein individually, on the complex, the ligand is entirely located on the spike protein RBD. The binding of terpinyl acetate involves residues from the interfaces of both proteins. The compound did not associate with these residues on both the ACE2 and the spike protein monomers 
only. This preference of terpinyl acetate to bind between the receptors merits further assays and clinical investigation. Contrary to the previous results where isoquercetin, guineensine, and brachyamide A were bound to the spike protein interface region, these three compounds were located on a different area on the complex. These secondary metabolites have higher surface area than terpinyl acetate, which might explain the reason why these compounds are not found in the narrow gap between the two proteins. As a recommendation, the development of ACE2-spike protein disruptors must consider the size of the ligand besides its affinity to the interface region of each protein.

The last step in determining how viable secondary metabolites can be for therapy is through ADME-Tox analysis. Tables 6 and 7 outline their abridged prediction profiles. All of the compounds except for the flavonoids had favorable bioavailability scores and lipophilicities at high certainties of toxicity prediction. The compounds guineensine and brachyamide A are markedly less hydrophilic and soluble as compared to the rest of the compounds, and are flagged as highly flexible. Terpinyl acetate, morin, and all of the P. nigrum L. secondary metabolites had high tendencies of intestinal absorption, while only terpinyl acetate and longicyclene had potential to pass through the blood-brain barrier. All of the compounds' leadlikeness violations did not exceed 3 and their estimated LD $_{50}$ values did not fall below 300 $\mathrm{mg} / \mathrm{kg}$. Both terpinyl acetate and $\beta$-bisabolene have a high chance to bind to PGH1 (or cyclooxygenase 1), while all $P$. nigrum L. secondary metabolites bind to amine oxidase, as reported in literature. ${ }^{[42]}$ The compounds from P. nigrum L. and the flavonoid glycosides from P. guajava L. all had high probabilities of immunotoxicity.

\section{Discussion}

Secondary metabolites have always had great importance in the search for remedies of various diseases. In this research, a handful of $P$. guajava L. and $P$. nigrum L. isolates have been extensively studied for their antiviral properties against the novel SARS-CoV-2 coronavirus. The protein targets are the viral spike protein, its priming enzyme TMPRSS2, and its receptor ACE2. Eight guava and seven black pepper secondary metabolites were docked in silico to these three receptors and the ACE2-spike protein complex. Flavonoids, particularly morin-3-O-lyxoside, had the highest affinities to all of the receptors. However, the screened flavonoid glycosides had the most structural alerts among the secondary metabolite ligands with regard to ADME-Tox predictions. In order to become viable candidates, the adverse effects of these compounds must be minimized, through iterative lead optimization.

In the context of SARS-CoV-2 infection, inhibition of TMPRSS2 protease leads to viral pathogenesis suppres$\operatorname{sion}^{[6,30,31]}$. The druggable sites of the enzyme, however, has yet to be explored. Here, it was observed that none of the screened molecules bind to the TMPRSS2 charge transfer pocket. Instead, the ligands bind to the same region as the binding site of the known TMPRSS2 inhibitor drug, camostat ${ }^{[22]}$. In the absence of a molecular evidence of TMPRSS2 inactivation by camostat, this homogeneity in terms of binding sites might provide insights on the effect of these secondary metabolites on the protease's function. 
For the ACE2, spike protein, and ACE2-spike complex systems, the ligands were seen to have higher binding affinities toward the ACE2 monomer. In terms of binding sites, however, some ligands were seen to bind to the interface of the complex rather than their respective ACE2 binding sites. The interactions of isoquercetin, terpinyl acetate, guineensine, and brachyamide A with this region can be further analyzed to determine if their binding leads to a reduced virulence of SARS-CoV-2.

Besides their potential to associate with the ACE2-spike complex, the screened secondary metabolites may also provide remedy to COVID-19 in another manner. A study showed that the immunomodulatory activity of dexamethasone, an immunosuppressant and steroid drug, reduced mortalities in COVID-19 patients that required respiratory support ${ }^{[43]}$. The secondary metabolites considered in this study also showed similar immunomodulatory activities ${ }^{[31,44]}$. If not as antivirals, the secondary metabolites are recommended for development as immunosuppressants. This strategy on addressing infection by attenuating host defenses, however, remains highly controversial and is still under critical discussion. ${ }^{[45]}$

\section{Conclusion}

Secondary metabolites from $P$. guajava L. and $P$. nigrum L. have shown considerable binding to key proteins involved in the virulence of SARS-CoV-2, while also having relatively benign ADME-Tox profiles. The screened molecules share a binding site on the priming protease TMPRSS2 with the known inhibitor camostat. Whether or not the secondary metabolites affect TMPRSS2 function and spike protein priming should be investigated in succeeding studies. Terpinyl acetate locates itself between spike protein RBD and ACE2. Remarkably, this compound does not bind to the interface region of either spike protein or ACE2 monomer. Considering that this compound has the least molecular weight among the screened secondary metabolites, the design of small and light disruptors of spike protein RBD recognition might be important in determining a potential COVID-19 drug.

While the pace of COVID-19 drug discovery has gone up, and countries are recording weeks of zero incidence, the SARS-CoV-2 virus will likely keep recurring. ${ }^{[46]}$ The "new normal" impacts the economy negatively and creates obstacles in the development of antivirals and vaccines. Secondary metabolites, which are inexpensive and readily obtainable, can be a great source of antiviral compounds. In this study, P. guajava L. and P. nigrum L. compounds were reported to have considerable interactions with TMPRSS2, spike protein, and ACE2. More secondary metabolites from these flora and from other natural products may soon be docked in the following months, to enrich the pool of anti-COVID-19 therapeutics with candidate compounds. 


\section{Acknowledgement}

We thank the Department of Science and Technology-Advanced Science and Technology Institute (DOST-ASTI) CoARE Facility and the UP Diliman College of Science Computational Science Research Center (CSRC) for providing the necessary computational resources.

\section{References}

[1] World Health Organization. WHO Statement regarding cluster of pneumonia cases in Wuhan, China, January 2020. URL https://www.who.int/china/news/detail/ 09-01-2020-who-statement-regarding-cluster-of-pneumonia-cases-in-wuhan-china.

[2] Carl Heneghan, Jon Brassey, and Tom Jefferson. COVID-19: What proportion are asymptomatic?, April 2020. URL https://www. cebm.net/covid-19/covid-19-what-proportion-are-asymptomatic/.

[3] Spyridoula Anastasopoulou and Mouzaki Athanasia. The biology of SARS-CoV-2 and the ensuing COVID-19. Achaiki Iatriki, 39(1):29-35, April 2020.

[4] Penghui Yang and Xiliang Wang. COVID-19: a new challenge for human beings. Cellular \& Molecular Immunology, March 2020. ISSN 1672-7681, 2042-0226. doi: 10.1038/s41423-020-0407-x.

[5] Xiaolu Tang, Changcheng Wu, Xiang Li, Yuhe Song, Xinmin Yao, Xinkai Wu, Yuange Duan, Hong Zhang, Yirong Wang, Zhaohui Qian, Jie Cui, and Jian Lu. On the origin and continuing evolution of SARS-CoV-2. National Science Review, page nwaa036, March 2020. ISSN 2095-5138, 2053-714X. doi: 10.1093/nsr/nwaa036.

[6] Markus Hoffmann, Hannah Kleine-Weber, Simon Schroeder, Nadine Krüger, Tanja Herrler, Sandra Erichsen, Tobias S. Schiergens, Georg Herrler, Nai-Huei Wu, Andreas Nitsche, Marcel A. Müller, Christian Drosten, and Stefan Pöhlmann. SARS-CoV-2 Cell Entry Depends on ACE2 and TMPRSS2 and Is Blocked by a Clinically Proven Protease Inhibitor. Cell, page S0092867420302294, March 2020. ISSN 00928674. doi: 10.1016/j.cell. 2020.02 .052 .

[7] David Cyranoski. Profile of a Killer Virus. Technical report, May 2020.

[8] Ewen Callaway, Heidi Ledford, and Smriti Mallapaty. Six months of coronavirus: the mysteries scientists are still racing to solve. Nature, 583(7815):178-179, July 2020. ISSN 0028-0836, 1476-4687. doi: 10.1038/ d41586-020-01989-z. URL http://www . nature.com/articles/d41586-020-01989-z.

[9] Daniel Blanco-Melo, Benjamin E Nilsson-Payant, Wen-Chun Liu, Skyler Uhl, Daisy Hoagland, Rasmus Møller, Tristan X Jordan, Kohei Oishi, Maryline Panis, David Sachs, et al. Imbalanced host response to sars-cov-2 drives development of covid-19. Cell, 2020.

[10] Christy Harrison. The Biology and Immunology of COVID-19 Susceptibility. Technical report, June 2020. URL https://asm.org/Articles/2020/June/ The-Biology-and-Immunology-of-COVID-19-Susceptibil. 
[11] Michele Catanzaro, Francesca Fagiani, Marco Racchi, Emanuela Corsini, Stefano Govoni, and Cristina Lanni. Immune response in COVID-19: addressing a pharmacological challenge by targeting pathways triggered by SARS-CoV-2. Signal Transduction and Targeted Therapy, 5(1):84, December 2020. ISSN 2059-3635. doi: 10.1038/s41392-020-0191-1. URL http://www . nature.com/articles/s41392-020-0191-1.

[12] Robert J. Mason. Pathogenesis of COVID-19 from a cell biology perspective. European Respiratory Journal, 55(4):2000607, April 2020. ISSN 0903-1936, 1399-3003. doi: 10.1183/13993003.00607-2020. URL http:// erj.ersjournals. com/lookup/doi/10.1183/13993003.00607-2020.

[13] Carmen Gil, Tiziana Ginex, Inés Maestro, Vanesa Nozal, Lucía Barrado-Gil, Miguel Ángel Cuesta-Geijo, Jesús Urquiza, David Ramírez, Covadonga Alonso, Nuria E. Campillo, and Ana Martinez. COVID-19: Drug Targets and Potential Treatments. Journal of Medicinal Chemistry, page acs.jmedchem.0c00606, June 2020. ISSN 00222623, 1520-4804. doi: 10.1021/acs.jmedchem.0c00606. URL https://pubs . acs.org/doi/10.1021/acs . jmedchem.0c00606.

[14] Dhanashree Jagtap, Selvaa Kumar C, Smita Mahale, and Vainav Patel. Modelling and docking of Indian SARSCoV-2 spike protein 1 with ACE2: implications for co-morbidity and therapeutic intervention. arXiv:2004.06361 [q-bio], April 2020. URL http://arxiv .org/abs/2004.06361. arXiv: 2004.06361.

[15] Houcemeddine Othman, Zied Bouslama, Jean-Tristan Brandenburg, Jorge da Rocha, Yosr Hamdi, Kais Ghedira, Najet Srairi-Abid, and Scott Hazelhurst. Interaction of the spike protein RBD from SARS-CoV-2 with ACE2: Similarity with SARS-CoV, hot-spot analysis and effect of the receptor polymorphism. Biochemical and Biophysical Research Communications, 527(3):702-708, June 2020. ISSN 0006291X. doi: 10.1016/j.bbrc.2020. 05.028. URL https://linkinghub.elsevier.com/retrieve/pii/S0006291X20309360.

[16] Micholas Smith and Jeremy C. Smith. Repurposing Therapeutics for COVID-19: Supercomputer-Based Docking to the SARS-CoV-2 Viral Spike Protein and Viral Spike Protein-Human ACE2 Interface. preprint, March 2020.

[17] F. Li. PDB ID: 2AJF. Structure of SARS Coronavirus Spike Receptor-Binding Domain Complexed with Receptor. Science, 309(5742):1864-1868, September 2005. ISSN 0036-8075, 1095-9203. doi: 10.1126/science. 1116480 .

[18] Wu, K., Peng, G., Wilken, M., Geraghty, R., Li, F. PDB ID: 3SCI. SARS coronavirus: mechanism of host receptor adaptation and rational prediction of future evolution. doi: DOI:10.2210/pdb3SCI/pdb.

[19] Wenfei Song, Miao Gui, Xinquan Wang, and Ye Xiang. PDB ID: 6ACK. Cryo-EM structure of the SARS coronavirus spike glycoprotein in complex with its host cell receptor ACE2. PLOS Pathogens, 14(8):e1007236, August 2018. ISSN 1553-7374. doi: 10.1371/journal.ppat.1007236.

[20] Renhong Yan, Yuanyuan Zhang, Yaning Li, Lu Xia, Yingying Guo, and Qiang Zhou. Structural basis for the recognition of SARS-CoV-2 by full-length human ACE2. Science, 367(6485):1444-1448, March 2020. ISSN 0036-8075, 1095-9203. doi: 10.1126/science.abb2762. 
[21] Yadi Zhou, Yuan Hou, Jiayu Shen, Yin Huang, William Martin, and Feixiong Cheng. Network-based drug repurposing for novel coronavirus 2019-nCoV/SARS-CoV-2. Cell Discovery, 6(1):14, December 2020. ISSN 20565968. doi: 10.1038/s41421-020-0153-3. URL http://www. nature. com/articles/s41421-020-0153-3.

[22] Maurice De Jesus, Jokent Gaza, Hiyas Junio, and Ricky Nellas. Aromatherapy vs SARS-CoV-2: The therapeutic potential of White Flower Oils. 2020. Manuscript submitted for publication.

[23] Canrong Wu, Yang Liu, Yueying Yang, Peng Zhang, Wu Zhong, Yali Wang, Qiqi Wang, Yang Xu, Mingxue Li, Xingzhou Li, Mengzhu Zheng, Lixia Chen, and Hua Li. Analysis of therapeutic targets for SARS-CoV-2 and discovery of potential drugs by computational methods. Acta Pharmaceutica Sinica B, page S2211383520302999, February 2020. ISSN 22113835. doi: 10.1016/j.apsb.2020.02.008.

[24] Jürgen Reichling. Plant-Microbe Interactions and Secondary Metabolites with Antibacterial, Antifungal and Antiviral Properties. In Jeremy A Roberts, editor, Annual Plant Reviews online, pages 214-347. John Wiley \& Sons, Ltd, Chichester, UK, April 2018. ISBN 978-1-119-31299-4. doi: 10.1002/9781119312994.apr0420. URL http://doi.wiley.com/10.1002/9781119312994.apr0420.

[25] Khalid A. El Sayed. Natural Products as Antiviral Agents. In Studies in Natural Products Chemistry, volume 24, pages 473-572. Elsevier, 2000. ISBN 978-0-444-50643-6. doi: 10.1016/S1572-5995(00)80051-4. URL https://linkinghub.elsevier.com/retrieve/pii/S1572599500800514.

[26] Nongluk Sriwilaijaroen, Syuichi Fukumoto, Kenji Kumagai, Hiroaki Hiramatsu, Takato Odagiri, Masato Tashiro, and Yasuo Suzuki. Antiviral effects of Psidium guajava Linn. (guava) tea on the growth of clinical isolated H1N1 viruses: Its role in viral hemagglutination and neuraminidase inhibition. Antiviral Research, 94(2):139-146, May 2012. ISSN 01663542. doi: 10.1016/j.antiviral.2012.02.013. URL https://linkinghub.elsevier . com/retrieve/pii/S0166354212000563.

[27] Hany Khalil, Ahmed I. Abd El Maksoud, Tamer Roshdey, and Samir El- Masry. Guava flavonoid glycosides prevent influenza A virus infection via rescue of P53 activity. Journal of Medical Virology, 91(1):45-55, January 2019. ISSN 0146-6615, 1096-9071. doi: 10.1002/jmv.25295. URL https://onlinelibrary.wiley.com/ doi/abs/10.1002/jmv. 25295.

[28] Ce Mair, R Liu, Ag Atanasov, M Schmidtke, Vm Dirsch, and Jm Rollinger. Antiviral and anti-proliferative in vitro activities of piperamides from black pepper. Planta Medica, 81(S 01):S1-S381, December 2016. ISSN 0032-0943, 1439-0221. doi: 10.1055/s-0036-1596830. URL http://www. thieme-connect.de/DOI/DOI? $10.1055 / \mathrm{s}-0036-1596830$.

[29] Zhi-Yong Jiang, Wen-Feng Liu, Xue-Mei Zhang, Jie Luo, Yun-Bao Ma, and Ji-Jun Chen. Anti-HBV active constituents from Piper longum. Bioorganic \& Medicinal Chemistry Letters, 23(7):2123-2127, April 2013. ISSN 0960894X. doi: 10.1016/j.bmcl.2013.01.118. URL https://linkinghub.elsevier.com/retrieve/ pii/S0960894X13001510. 
[30] Hsiao-Chien Lin and Jin-Yuarn Lin. Characterization of guava (Psidium guajava Linn) seed polysaccharides with an immunomodulatory activity. International Journal of Biological Macromolecules, 154:511-520, July 2020. ISSN 01418130. doi: 10.1016/j.jjbiomac.2020.03.137. URL https://linkinghub.elsevier.com/ retrieve/pii/S0141813019402936.

[31] E.S Sunila and G Kuttan. Immunomodulatory and antitumor activity of Piper longum Linn. and piperine. Journal of Ethnopharmacology, 90(2-3):339-346, February 2004. ISSN 03788741. doi: 10.1016/j.jep.2003.10.016. URL https://linkinghub.elsevier.com/retrieve/pii/S0378874103004021.

[32] Hidetoshi Arima and Gen-ichi Danno. Isolation of Antimicrobial Compounds from Guava ( Psidium guajava L.) and their Structural Elucidation. Bioscience, Biotechnology, and Biochemistry, 66(8):1727-1730, January 2002. ISSN 0916-8451, 1347-6947. doi: 10.1271/bbb.66.1727. URL http://www.tandfonline.com/doi/full/ $10.1271 / \mathrm{bbb} .66 .1727$.

[33] Corinna Dawid, Andrea Henze, Oliver Frank, Anneke Glabasnia, Mathias Rupp, Kirsten Büning, Diana Orlikowski, Matthias Bader, and Thomas Hofmann. Structural and Sensory Characterization of Key Pungent and Tingling Compounds from Black Pepper ( Piper nigrum L.). Journal of Agricultural and Food Chemistry, 60 (11):2884-2895, March 2012. ISSN 0021-8561, 1520-5118. doi: 10.1021/jf300036a. URL https://pubs . acs.org/doi/10.1021/jf300036a.

[34] Oleg Trott and Arthur J. Olson. AutoDock Vina: Improving the speed and accuracy of docking with a new scoring function, efficient optimization, and multithreading. Journal of Computational Chemistry, pages NA-NA, 2009. ISSN 01928651, 1096987X. doi: 10.1002/jcc.21334.

[35] Sebastian Salentin, Sven Schreiber, V. Joachim Haupt, Melissa F. Adasme, and Michael Schroeder. PLIP: fully automated protein-ligand interaction profiler. Nucleic Acids Research, 43(W1):W443-W447, July 2015. ISSN 0305-1048, 1362-4962. doi: 10.1093/nar/gkv315.

[36] Antoine Daina, Olivier Michielin, and Vincent Zoete. SwissADME: a free web tool to evaluate pharmacokinetics, drug-likeness and medicinal chemistry friendliness of small molecules. Scientific Reports, 7(1):42717, May 2017. ISSN 2045-2322. doi: 10.1038/srep42717.

[37] Priyanka Banerjee, Andreas O Eckert, Anna K Schrey, and Robert Preissner. ProTox-II: a webserver for the prediction of toxicity of chemicals. Nucleic Acids Research, 46(W1):W257-W263, July 2018. ISSN 0305-1048, 1362-4962. doi: 10.1093/nar/gky318.

[38] Andrew Waterhouse, Martino Bertoni, Stefan Bienert, Gabriel Studer, Gerardo Tauriello, Rafal Gumienny, Florian T Heer, Tjaart A P de Beer, Christine Rempfer, Lorenza Bordoli, Rosalba Lepore, and Torsten Schwede. Homology model O15393 from: SWISS-MODEL: homology modelling of protein structures and complexes. $\mathrm{Nu}$ cleic Acids Research, 46(W1):W296-W303, July 2018. ISSN 0305-1048, 1362-4962. doi: 10.1093/nar/gky427. 
[39] Jodie L. Guy, Richard M. Jackson, Hanne A. Jensen, Nigel M. Hooper, and Anthony J. Turner. Identification of critical active-site residues in angiotensin-converting enzyme-2 (ACE2) by site-directed mutagenesis. FEBS Journal, 272(14):3512-3520, July 2005. ISSN 1742-464X, 1742-4658. doi: 10.1111/j.1742-4658.2005.04756.x.

[40] Alberto Boldrini, Luca Terruzzi, Giovanni Spagnolli, Andrea Astolfi, Tania Massignan, Graziano Lolli, Maria Letizia Barreca, Emiliano Biasini, Pietro Faccioli, and Lidia Pieri. Identification of a Druggable Intermediate along the Folding Pathway of the SARS-CoV-2 Receptor ACE2. arXiv:2004.13493 [cond-mat, physics:physics, q-bio], April 2020. URL http://arxiv.org/abs/2004.13493. arXiv: 2004.13493.

[41] Jun Lan, Jiwan Ge, Jinfang Yu, Sisi Shan, Huan Zhou, Shilong Fan, Qi Zhang, Xuanling Shi, Qisheng Wang, Linqi Zhang, and Xinquan Wang. Structure of the SARS-CoV-2 spike receptor-binding domain bound to the ACE2 receptor. Nature, 581(7807):215-220, May 2020. ISSN 0028-0836, 1476-4687. doi: 10.1038/s41586-020-2180-5. URL http://www . nature.com/articles/s41586-020-2180-5.

[42] Seon A Lee, Seong Su Hong, Xiang Hua Han, Ji Sang Hwang, Gab Jin Oh, Kyong Soon Lee, Myung Koo Lee, Bang Yeon Hwang, and Jai Seup Ro. Piperine from the Fruits of Piper longum with Inhibitory Effect on Monoamine Oxidase and Antidepressant-Like Activity. CHEMICAL \& PHARMACEUTICAL BULLETIN, 53 (7):832-835, 2005. ISSN 0009-2363, 1347-5223. doi: 10.1248/cpb.53.832. URL http://joi.jlc.jst.go . jp/JST . JSTAGE/cpb/53.832? from=CrossRef.

[43] Peter Horby, Wei Shen Lim, Jonathan Emberson, Marion Mafham, Jennifer Bell, Louise Linsell, Natalie Staplin, Christopher Brightling, Andrew Ustianowski, Einas Elmahi, Benjamin Prudon, Christopher Green, Timothy Felton, David Chadwick, Kanchan Rege, Christopher Fegan, Lucy C Chappell, Saul N Faust, Thomas Jaki, Katie Jeffery, Alan Montgomery, Kathryn Rowan, Edmund Juszczak, J Kenneth Baillie, Richard Haynes, Martin J Landray, and RECOVERY Collaborative Group. Effect of Dexamethasone in Hospitalized Patients with COVID19: Preliminary Report. preprint, Infectious Diseases (except HIV/AIDS), June 2020. URL http://medrxiv . org/lookup/doi/10.1101/2020.06.22.20137273.

[44] Master David, T. Jawahar Abraham, T. S. Nagesh, and Harresh Adikesavalu. Immunomodulatory effect of Guavarine $\AA$, aqueous guava leaf extract, on ornamental Koi carp Cyprinus carpio var. koi L . 1758. Journal of Applied Aquaculture, 29(3-4):322-330, October 2017. ISSN 1045-4438, 1545-0805. doi: 10.1080/10454438. 2017.1363680. URL https://www.tandfonline.com/doi/full/10.1080/10454438.2017.1363680.

[45] James M. Sanders, Marguerite L. Monogue, Tomasz Z. Jodlowski, and James B. Cutrell. Pharmacologic Treatments for Coronavirus Disease 2019 (COVID-19): A Review. JAMA, April 2020. ISSN 0098-7484. doi: 10.1001/jama.2020.6019. URL https://jamanetwork. com/journals/jama/fullarticle/2764727.

[46] Jacqueline Howard. "Very unlikely" world can eradicate or eliminate coronavirus in current situation, WHO says. CNN, July 2020. URL https://edition.cnn.com/world/live-news/ coronavirus-pandemic-07-10-20-intl/h_6bf0e7a7363289cb0d9271a965df5e12. 
[47] Li Wen Shen, Hui Juan Mao, Yan Ling Wu, Yoshimasa Tanaka, and Wen Zhang. TMPRSS2: A potential target for treatment of influenza virus and coronavirus infections. Biochimie, 142:1-10, November 2017. ISSN 03009084. doi: 10.1016/j.biochi.2017.07.016.

[48] Zi-Wei Ye, Shuofeng Yuan, Kit-San Yuen, Sin-Yee Fung, Chi-Ping Chan, and Dong-Yan Jin. Zoonotic origins of human coronaviruses. International Journal of Biological Sciences, 16(10):1686-1697, 2020. ISSN 1449-2288. doi: 10.7150/ijbs.45472. URL http://www . ijbs . com/v16p1686.htm.

[49] Targeting COVID-19: the drugs being fast-tracked through clinical trials and how they work. The Pharmaceutical Journal, 2020. ISSN 2053-6186. doi: 10.1211/PJ.2020.20207949. URL http://www.pharmaceutical-journal.com/news-and-analysis/infographics/ targeting-covid-19-the-drugs-being-fast-tracked-through-clinical-trials-and-how-they-work/ 20207949. article.

[50] Mushtaq Hussain, Nusrat Jabeen, Anusha Amanullah, Ayesha Ashraf Baig, Basma Aziz, Sanya Shabbir, and Fozia Raza. Structural Basis of SARS-CoV-2 Spike Protein Priming by TMPRSS2. preprint, Bioinformatics, April 2020. URL http://biorxiv.org/lookup/doi/10.1101/2020.04.21.052639. 
Table 1: Docking results of $P$. guajava L. and $P$. nigrum L. extract secondary metabolite compounds against the ACE2-Spike complex, ACE2, Spike protein, and TMPRSS2 models.

\begin{tabular}{|c|c|c|c|c|c|c|c|c|c|c|c|c|}
\hline \multirow{2}{*}{ compound } & \multicolumn{12}{|c|}{ Binding energy $(\mathrm{kcal} / \mathrm{mol})$ to } \\
\hline & \multirow{2}{*}{ 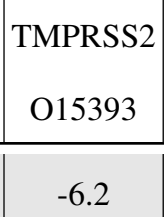 } & \multicolumn{3}{|c|}{$\begin{array}{c}\text { ACE2-spike } \\
\text { 2AJF 3SCI 6M17 }\end{array}$} & \multicolumn{4}{|c|}{$\begin{array}{c}\text { ACE2 } \\
\text { 2AJF.A 3SCI.A 6ACK.D 6M17.B }\end{array}$} & \multicolumn{4}{|c|}{$\begin{array}{c}\text { spike protein } \\
\text { 2AJF.E 3SCI.E 6ACK.A 6M17.E }\end{array}$} \\
\hline Isoquercetin & & -7.7 & -8.0 & -8.3 & -7.8 & -7.4 & -7.6 & -7.7 & -5.4 & -5.7 & -4.8 & -6.0 \\
\hline Terpinyl acetate & -4.0 & -5.0 & -5.2 & -4.6 & -5.6 & -5.2 & -5.1 & -4.7 & -4.4 & -3.6 & -4.2 & -4.7 \\
\hline Longicyclene & -4.9 & -6.2 & -5.8 & -6.1 & -5.9 & -6.3 & -6.1 & -5.8 & -4.7 & -4.5 & -4.6 & -5.3 \\
\hline$\beta$-bisabolene & -4.1 & -6.3 & -6.4 & -4.6 & -5.8 & -5.8 & -5.6 & -5.7 & -4.0 & -4.4 & -4.9 & -5.1 \\
\hline Caryophyllene & -4.7 & -5.9 & -6.2 & -6.1 & -5.9 & -6.5 & -6.4 & -6.4 & -4.4 & -4.5 & -4.9 & -6.0 \\
\hline Morin & -6.6 & -7.5 & -7.7 & -7.4 & -7.0 & -7.6 & -7.0 & -7.4 & -5.5 & -5.8 & -5.0 & -6.5 \\
\hline $\begin{array}{r}\text { Morin-3-O- } \\
\text { lyxoside }\end{array}$ & -6.3 & -8.1 & -7.8 & -7.4 & -7.9 & -7.8 & -7.9 & -7.3 & -6.0 & -6.0 & -5.1 & -6.6 \\
\hline $\begin{array}{l}\text { Morin-3-O- } \\
\text { arabinoside }\end{array}$ & -6.2 & -8.2 & -7.8 & -7.3 & -8.1 & -7.7 & -7.5 & -7.3 & -5.7 & -6.0 & -4.8 & -6.5 \\
\hline Piperine & -5.8 & -7.5 & -7.4 & -6.8 & -6.9 & -6.9 & -7.4 & -7.6 & -5.5 & -5.4 & -5.3 & -6.5 \\
\hline Piperyline & -5.6 & -7.5 & -7.6 & -7.2 & -6.6 & -7.0 & -7.2 & -7.1 & -5.2 & -5.4 & -5.0 & -6.4 \\
\hline Piperlongumine & -6.0 & -6.7 & -7.2 & -6.6 & -6.2 & -6.6 & -6.8 & -6.5 & -4.7 & -5.2 & -5.0 & -6.2 \\
\hline Guineensine & -5.3 & -7.0 & -7.4 & -6.5 & -6.1 & -5.9 & -5.9 & -5.8 & -4.4 & -4.6 & -4.8 & -4.8 \\
\hline Brachyamide A & -5.5 & -7.8 & -7.6 & -6.2 & -6.3 & -6.1 & -6.3 & -6.2 & -4.4 & -4.8 & -4.6 & -5.1 \\
\hline Piperoleine B & -6.5 & -6.5 & -7.5 & -6.3 & -6.2 & -7.0 & -6.5 & -6.3 & -5.0 & -5.1 & -5.2 & -6.1 \\
\hline Pipernonaline & -6.5 & -7.6 & -7.7 & -6.8 & -6.2 & -7.1 & -7.2 & -6.0 & -5.0 & -5.6 & -4.9 & -5.1 \\
\hline Camostat $^{[22]}$ & -6.0 & -7.2 & -7.1 & -6.5 & -6.6 & -7.3 & -7.2 & -6.4 & -5.0 & -5.4 & -5.1 & -5.9 \\
\hline
\end{tabular}


Table 2: List of interactions of P. guajava L. and P. nigrum L. secondary metabolite compounds with human TMPRSS2 receptor. Residue text are colored according to the nature of non-covalent bonding to the ligand: black if hydrophobic, red if H-bonding, green if salt bridge, blue if $\pi$-stacking, and brown if $\pi$-cation.

\begin{tabular}{l|l}
\hline compound & $\mathrm{O} 15393$ \\
\hline $\begin{array}{l}\text { Isoquercetin } \\
\text { Terpinyl acetate }\end{array}$ & $\mathrm{V} 479, \mathrm{I} 21, \mathrm{~F} 480, \mathrm{~W} 489, \mathrm{~V} 479, \mathrm{~N} 343, \mathrm{M} 478, \mathrm{D} 482, \mathrm{~W} 483, \mathrm{R} 486, \mathrm{~W} 483$ \\
Longicyclene & $\mathrm{I} 21, \mathrm{P} 369$ \\
$\beta$-bisabolene & $\mathrm{I} 221, \mathrm{~T} 369$ \\
Caryophyllene & $\mathrm{I} 221, \mathrm{~K} 223, \mathrm{C} 148, \mathrm{~V} 149, \mathrm{~K} 223, \mathrm{P} 369, \mathrm{~K} 223$ \\
Morin & $\mathrm{D} 482, \mathrm{~N} 336, \mathrm{~W} 483, \mathrm{R} 486, \mathrm{~W} 483$ \\
Morin-3-O-lyxoside & $\mathrm{D} 482, \mathrm{~W} 483, \mathrm{~N} 336, \mathrm{~W} 483, \mathrm{R} 486, \mathrm{~W} 483$ \\
Morin-3-O-arabinoside & $\mathrm{I} 221, \mathrm{P} 369, \mathrm{~W} 483, \mathrm{~N} 336, \mathrm{~W} 483$ \\
Piperine & $\mathrm{V} 149, \mathrm{I} 221, \mathrm{~K} 223, \mathrm{~K} 224, \mathrm{P} 369, \mathrm{C} 148, \mathrm{~V} 149$ \\
Piperyline & $\mathrm{D} 220, \mathrm{I} 221, \mathrm{P} 369, \mathrm{~T} 481, \mathrm{D} 482, \mathrm{~W} 483, \mathrm{D} 482, \mathrm{R} 486, \mathrm{~W} 483$ \\
Piperlongumine & $\mathrm{P} 369, \mathrm{P} 422, \mathrm{~A} 423, \mathrm{~V} 479, \mathrm{~F} 480, \mathrm{~T} 481, \mathrm{D} 482, \mathrm{~W} 483$ \\
Guineensine & $\mathrm{P} 369, \mathrm{P} 422, \mathrm{~A} 423, \mathrm{~V} 479, \mathrm{~F} 480, \mathrm{D} 482, \mathrm{~W} 483$ \\
Brachyamide A & $\mathrm{I} 221, \mathrm{~K} 223, \mathrm{P} 369, \mathrm{~T} 481, \mathrm{C} 148$ \\
Piperoleine B & $\mathrm{I} 221, \mathrm{~K} 223, \mathrm{P} 369, \mathrm{C} 148, \mathrm{G} 370$ \\
Pipernonaline &
\end{tabular}


Table 3: List of interactions of P. guajava L. and P. nigrum L. secondary metabolite compounds with human ACE2 receptors. Residue text are colored according to the nature of non-covalent bonding to the ligand: black if hydrophobic, red if H-bonding, green if salt bridge, blue if $\pi$-stacking, and brown if $\pi$-cation.

\begin{tabular}{|c|c|c|c|c|}
\hline compound & 2AJF.A & 3SCI.A & 6ACK.D & 6M17.B \\
\hline Isoquercetin & \begin{tabular}{|l} 
F274,L410,I446,L370,H374, \\
E406,S409,Q442,R518
\end{tabular} & $\begin{array}{l}\text { S47,D350,D382,Y385, } \\
\text { N394,W349 }\end{array}$ & F274,K441,T371,E406 & $\begin{array}{l}\text { D350,N394,H401,D350, } \\
\text { G395,H401 }\end{array}$ \\
\hline Terpinyl acetate & Q98,K562 & F40,W349,D350 & L144,W271,F504,R273 & L370,K441 \\
\hline Longicyclene & F32,L73,A99,L100,L391 & L95,V209,K562,P565 & Y127,L144,W271,F504 & L144,W271,F274,L503 \\
\hline$\beta$-bisabolene & D269,W271,F504 & D269,W271,F504 & $\mathrm{W} 271, \mathrm{~F} 274, \mathrm{~F} 504$ & F40,W349,D350 \\
\hline Caryophyllene & F40,L73,F390,L391 & V209,K562,P565 & L144,D269,W271,F504 & L95,V209,K562,P565 \\
\hline Morin & A348,G395,E398,H401,H378 & $\begin{array}{l}\text { L95,K562,L95,Q98,Q102, } \\
\text { Y196,N210,E564 }\end{array}$ & $\begin{array}{l}\text { Y202,D206,Q102,Y199, } \\
\text { W203,G205,D206,S511 }\end{array}$ & L95,Y196,W566,K564 \\
\hline $\begin{array}{l}\text { Morin-3-O- } \\
\text { lyxoside }\end{array}$ & $\begin{array}{l}\text { F40,T347,S43,S47,N51, } \\
\text { D350,D382,W349 }\end{array}$ & $\begin{array}{l}\text { F40,T347,S43,S47,N51, } \\
\text { D350,D382,W349 }\end{array}$ & $\begin{array}{l}\text { A99,L391,L95,Y202, } \\
\text { D206,E208,K562,K562 }\end{array}$ & D350,D350,F40 \\
\hline $\begin{array}{l}\text { Morin-3-O- } \\
\text { arabinoside }\end{array}$ & $\begin{array}{l}\text { F40,T347,S43,S47,N51, } \\
\text { T347,D350,W349 }\end{array}$ & $\begin{array}{l}\text { F40,T347,S43,S47,N51, } \\
\text { T347,D350,W349 }\end{array}$ & T276,T445,H374,Q522 & W349,S47,D350,F40 \\
\hline Piperine & $\begin{array}{l}\text { F40,W69,A99,L100,F390, } \\
\text { D350,N394 }\end{array}$ & Y202 & $\begin{array}{l}\text { Q98,Y202,K562,Q102, } \\
\text { W203,S511 }\end{array}$ & $\begin{array}{l}\text { F40,W69,L73,F390, } \\
\text { L391,R393,K353,R393 }\end{array}$ \\
\hline Piperyline & F40,W69,F390,D350,N394 & $\begin{array}{l}\text { Y127,L144,E145,W271,F274, } \\
\text { F504,E145,R273,Y127 }\end{array}$ & $\begin{array}{l}\text { Q98,A99,Y202,D206,K562, } \\
\text { Q102,Y196,Y199 }\end{array}$ & $\begin{array}{l}\text { F40,W69,L73,F390, } \\
\text { R393,N394,R393 }\end{array}$ \\
\hline Piperlongumine & $\begin{array}{l}\text { Y127,L144,E145,W271, } \\
\text { F274,Y127,N149 }\end{array}$ & $\begin{array}{l}\text { Y127,L143,L144,E145, } \\
\text { W271,L503,F504,R273 }\end{array}$ & $\begin{array}{l}\text { Q98,Y202,D206,V209,K562, } \\
\text { Q102,Y196,Y199,D206 }\end{array}$ & $\begin{array}{l}\text {, I291,L370,P415,E430, } \\
\text { T434,E435,F438 }\end{array}$ \\
\hline Guineensine & F40,W349,H378,H401,W349 & W349,F390,D350,H401 & $\begin{array}{l}\text { F274,L370,T371,K441, } \\
\text { S409,Q442 }\end{array}$ & $\begin{array}{l}\text { Y127,L144,E145,W271, } \\
\text { F504,F504 }\end{array}$ \\
\hline Brachyamide A & F40,W349,D350,W349 & F40,W349,D350,W349 & $\begin{array}{l}\text { F274,L370,T371,K441, } \\
\text { S409,Q442 }\end{array}$ & $\begin{array}{l}\text { F40,W69,F390,D350, } \\
\text { N394 }\end{array}$ \\
\hline Piperoleine B & T347,W349,D350,S47,W349 & $\begin{array}{l}\text { Y127,L144,E145,D269, } \\
\text { W271,L503,F504 }\end{array}$ & F274,L370,H374,K441,T445 & $\begin{array}{l}\text { Y127,L144,E145,W271, } \\
\text { F274,F504,F504,H505 }\end{array}$ \\
\hline Pipernonaline & F40,W349,D350,W349 & $\begin{array}{l}\text { L144,N149,A153,D269,W271, } \\
\text { F274,F504,E145,D269,Y127 }\end{array}$ & $\begin{array}{l}\text {,F40,W69,L73,F390,L391, } \\
\text { F40 }\end{array}$ & $\begin{array}{l}\text { Y127,L144,E145,W271, } \\
\text { F504 }\end{array}$ \\
\hline
\end{tabular}


Table 4: List of interactions of $P$. guajava L. and P. nigrum L. secondary metabolite compounds with spike protein RBD receptor. Residue text are colored according to the nature of non-covalent bonding to the ligand: black if hydrophobic, red if H-bonding, green if salt bridge, blue if $\pi$-stacking, and brown if $\pi$-cation.

\begin{tabular}{|c|c|c|c|c|}
\hline compound & 2AJF.E & 3SCI.E & 6ACK.A & 6M17.E \\
\hline Isoquercetin & $\begin{array}{l}\text { W340,R342,W340, } \\
\text { R342,F451 }\end{array}$ & $\begin{array}{l}\text { W340,F451,W340, } \\
\text { R342,R453 }\end{array}$ & $\begin{array}{l}\text { K390,I405,D392,Q396,Y442, } \\
\text { N479 }\end{array}$ & $\begin{array}{l}\text { Y491,R390,Y436,Y481, } \\
\text { Q484,N487,G488,Y491 }\end{array}$ \\
\hline Terpinyl acetate & $\begin{array}{l}\text { P335,A339,N437, Y438, } \\
\text { S336 }\end{array}$ & W340,R342 & V404,I405,Y440,Y442 & $\begin{array}{l}\text { F329,V354,L355,F361, } \\
\text { W423 }\end{array}$ \\
\hline Longicyclene & $\begin{array}{l}\text { P335,Y338,A339, Y438, } \\
\text { K439 }\end{array}$ & W340 & V404,I405,Y440 & F329,V354,L355,F361 \\
\hline$\beta$-bisabolene & P335,N437,Y438,K439 & W340,R342,R453 & K390,V404,I405,Y440,Y442 & $\begin{array}{l}\text { F329,V354,L355,F361, } \\
\text { W423 }\end{array}$ \\
\hline Caryophyllene & Y338,A339, Y438 & W340 & V404,Y440,Y442,L443 & F329,L355,F361,W423 \\
\hline Morin & $\begin{array}{l}\text { W340,R342,E452,R453, } \\
\text { W340,R342,R453,R453 }\end{array}$ & W340,F451,W340,R342 & I405,Q396,Y442,Y440,Y442 & $\begin{array}{l}\text { V354,L355,S358,S360, } \\
\text { F325 }\end{array}$ \\
\hline $\begin{array}{l}\text { Morin-3-O- } \\
\text { lyxoside }\end{array}$ & $\begin{array}{l}\text { W340,R342,R453,E341, } \\
\text { R342 }\end{array}$ & R342,W340,R342,W340 & $\begin{array}{l}\text { I405,K390,D393,V404,I405,Y440, } \\
\text { Y442,N479, Y481,K390,Y442 }\end{array}$ & $\begin{array}{l}\text { F329,F361,N330,S360, } \\
\text { N427,W423 }\end{array}$ \\
\hline $\begin{array}{l}\text { Morin-3-O- } \\
\text { arabinoside }\end{array}$ & $\begin{array}{l}\text { R342,R453,E341,R342, } \\
\text { R453,R453 }\end{array}$ & R342,W340,R342,W340 & $\begin{array}{l}\text { V404,I405,K390,Q396,V404, } \\
\text { I405,Y440 }\end{array}$ & $\begin{array}{l}\text { F329,F361,S360,N427, } \\
\text { W423 }\end{array}$ \\
\hline Piperine & W340,F451,R453 & $\begin{array}{l}\text { R342,R453,R342,W340, } \\
\text { R453 }\end{array}$ & V404,I405,Y408,Y442 & T363,V394,V489,T363 \\
\hline Piperyline & $\begin{array}{l}\text { W340,R342,E452,R342, } \\
\text { R453 }\end{array}$ & $\begin{array}{l}\text { R342,R449,R453,R342, } \\
\text { W340,R453 }\end{array}$ & V404,I405,Y408,Y442 & V354,W423,S360,F325 \\
\hline Piperlongumine & W340,R342,F451,R453 & $\begin{array}{l}\text { R342,R449,E452,R453, } \\
\text { R342,W340,R453 }\end{array}$ & $\begin{array}{l}\text { V404,I405,Y408, Y440,Y442, } \\
\text { Q396 }\end{array}$ & $\begin{array}{l}\text { F329,V354,L355,F361, } \\
\text { W423,N330,F325 }\end{array}$ \\
\hline Guineensine & $\begin{array}{l}\text { W340,R342,K344,Y383, } \\
\text { R453 }\end{array}$ & $\begin{array}{l}\text { R342,K344,R453,R342, } \\
\text { W340,R453 }\end{array}$ & V404,I405,Y408,Y442,N479 & L439,F477,Q479,S480 \\
\hline Brachyamide A & $\begin{array}{l}\text { W340,R342,K344,Y383, } \\
\text { R453 }\end{array}$ & $\begin{array}{l}\text { W340,R453,R342,W340, } \\
\text { R453 }\end{array}$ & $\begin{array}{l}\text { V404,I405,Y408,Y442,N479, } \\
\text { K390 }\end{array}$ & $\begin{array}{l}\text { L439,Y475,F476,L478, } \\
\text { S480 }\end{array}$ \\
\hline Piperoleine B & $\begin{array}{l}\text { W340,R342,K344,Y383, } \\
\text { R453 }\end{array}$ & $\begin{array}{l}\text { W340,R342,K344,F451, } \\
\text { R342 }\end{array}$ & $\begin{array}{l}\text { V404,I405,Y408, Y442,N479, } \\
\text { Y442 }\end{array}$ & $\begin{array}{l}\text { F329,V354,F361,W423, } \\
\text { N424,S360 }\end{array}$ \\
\hline Pipernonaline & $\begin{array}{l}\text { W340,F451,R453,R342, } \\
\text { R453 }\end{array}$ & W340,R342,K344,Y383 & V404,I405,Y408,Y442,N479 & $\begin{array}{l}\text { T363,K365,V394,R395, } \\
\text { A398 }\end{array}$ \\
\hline
\end{tabular}


Table 5: List of interactions of P. guajava L. and P. nigrum L. secondary metabolite compounds with ACE2-spike protein complex receptors. Residue text are colored according to the nature of non-covalent bonding to the ligand: black if hydrophobic, red if H-bonding, green if salt bridge, blue if $\pi$-stacking, and brown if $\pi$-cation. All residues belong to the ACE2 receptor unless marked with an asterisk, meaning they are located on the spike protein.

\begin{tabular}{|c|c|c|c|}
\hline compound & $2 \mathrm{AJF}$ & $3 \mathrm{SCI}$ & $6 \mathrm{M} 17$ \\
\hline Isoquercetin & \begin{tabular}{|l} 
F274,L410,I446,L370,H374, \\
E406,S409,Q442,R518
\end{tabular} & $\begin{array}{l}\text { K562,Q98,Y196,E208,G395, } \\
\text { A396,K562,K562,K562 }\end{array}$ & $\begin{array}{l}\text { L95,Q98,N210,K562,L95,Q98,G205, } \\
\text { D206,N210,A396,K562,K562 }\end{array}$ \\
\hline Terpinyl acetate & $\begin{array}{l}\text { E35,D38,L39,Y436*,D480*, } \\
\text { D480* }\end{array}$ & F40,W349,D350 & $\mathrm{W} 271, \mathrm{~F} 274, \mathrm{~T} 276$ \\
\hline Longicyclene & F40,W69,F390,R393 & L95,Q98,A99 & I291,L370,A413,F438,K441 \\
\hline$\beta$-bisabolene & F40,W69,L73,L100,F390,L391 & F32,F40,L73,L100,F390,L391 & E527,Q531,H535,L539 \\
\hline Caryophyllene & D269,W271,R273,F274,F504 & F32,W69,L73,L391 & $\mathrm{F} 329^{*}, \mathrm{~L} 355^{*}, \mathrm{~F} 361^{*}, \mathrm{~W} 423^{*}$ \\
\hline Morin & F390,D350,R393,N394,F40 & E208,K562,Q98 & F40,F390,K353,R393 \\
\hline Morin-3-O-lyxoside & $\begin{array}{l}\text { F40,T347,S43,S47,N51,D350, } \\
\text { W349 }\end{array}$ & $\begin{array}{l}\text { Q98,E208,Q102,Y202,D206, } \\
\text { E208,K562,K562 }\end{array}$ & F40,Y385,L391,R393,N394,F40 \\
\hline $\begin{array}{l}\text { Morin-3-O- } \\
\text { arabinoside }\end{array}$ & $\begin{array}{l}\text { F40,T347,S43,S47,N51,T347, } \\
\text { D350,W349 }\end{array}$ & $\begin{array}{l}\text { Q98,Q98,Q102,Y202,D206, } \\
\text { E208,K562,K562 }\end{array}$ & W349,D350,S47,D350,R393,F40 \\
\hline Piperine & F32,F40,L100,D350,F390,L391 & F32,F40,L73,D350,F390,L391 & L95,Q102,N210 \\
\hline Piperyline & $\begin{array}{l}\text { F32,F40,W69,L73,L100,F390, } \\
\text { L391,R393 }\end{array}$ & $\begin{array}{l}\text { F32,F40,W69,L73,L100,F390, } \\
\text { L391,R393 }\end{array}$ & $\begin{array}{l}\text { F40,L73,L391,R393,K353,N394, } \\
\text { R393 }\end{array}$ \\
\hline Piperlongumine & $\begin{array}{l}\text { F32,F40,W69,L73,L100,D350, } \\
\text { F390,L391,R393 }\end{array}$ & $\begin{array}{l}\text { F32,F40,W69,L73,L100,F390, } \\
\text { R393 }\end{array}$ & F40,A99,F390,R393,N394,R393 \\
\hline Guineensine & F40,W69,D350,F390 & $\begin{array}{l}\text { F32,F40,L73,L100,W349,D350, } \\
\text { F390,L391 }\end{array}$ & F40,D350,F390,R393,S47 \\
\hline Brachyamide A & $\begin{array}{l}\text { F40,W69,L73,L100,D350,H378, } \\
\text { F390,L391,R393 }\end{array}$ & $\begin{array}{l}\text { F32,F40,W69,L73,L100,A348, } \\
\text { F390,L391,N394 }\end{array}$ & F40,T347,W349,F390,R393,S47 \\
\hline Piperoleine B & W349,D350,S47,W349 & $\begin{array}{l}\text { F32,F40,W69,L73,D350,F390, } \\
\text { L391 }\end{array}$ & W349,D350,F390,R393,F40,F390 \\
\hline Pipernonaline & F40,W69,W349,D350,F390,L391 & $\begin{array}{l}\text { F32,F40,L73,L100,D350,F390, } \\
\text { L391,Y385 }\end{array}$ & $\begin{array}{l}\text { L85,L95,V209,N210,P565,N210, } \\
\text { R219,W566 }\end{array}$ \\
\hline
\end{tabular}


Table 6: ADME-Tox predictions for guava secondary metabolite compounds. Key: PGH1 = prostaglandin G/H synthase 1 or cyclooxygenase 1 , ANDR = androgen receptor, GCR = glucocorticoid receptor. Organ toxicity predictions POS for positive and NEG for negative are reported with the corresponding prediction accuracy.

\begin{tabular}{|c|c|c|c|c|c|c|c|c|}
\hline & isoquercetin & $\begin{array}{l}\text { terpinyl } \\
\text { acetate }\end{array}$ & longicyclene & $\beta$-bisabolene & caryophyllene & morin & $\begin{array}{l}\text { morin-3-O- } \\
\text { lyxoside }\end{array}$ & $\begin{array}{l}\text { morin-3-O- } \\
\text { arabinoside }\end{array}$ \\
\hline Consensus $\log \mathrm{P}$ & -0.58 & 3.04 & 4.39 & 4.83 & 4.25 & 1.15 & -0.25 & -0.21 \\
\hline $\begin{array}{l}\text { Consensus } \\
\text { solubility }\end{array}$ & Soluble & Soluble & $\begin{array}{l}\text { Moderately } \\
\text { soluble }\end{array}$ & $\begin{array}{l}\text { Moderately } \\
\text { soluble }\end{array}$ & Soluble & Soluble & Soluble & Soluble \\
\hline GI absorption & Low & High & Low & Low & Low & High & Low & Low \\
\hline BBB permeant & No & Yes & Yes & No & No & No & No & No \\
\hline $\begin{array}{l}\text { Bioavailability } \\
\text { score }\end{array}$ & 0.11 & 0.55 & 0.55 & 0.55 & 0.55 & 0.56 & 0.11 & 0.11 \\
\hline $\begin{array}{l}\text { Leadlikeness } \\
\text { violations }\end{array}$ & 1 & 2 & 2 & 2 & 2 & 0 & 1 & 1 \\
\hline $\begin{array}{l}\text { Predicted LD50 } \\
(\mathrm{mg} / \mathrm{kg})\end{array}$ & 500 & 4800 & 3660 & 4400 & 5000 & 500 & 500 & 500 \\
\hline $\begin{array}{l}\text { High probability } \\
\text { binding target }\end{array}$ & (no prediction) & PGH1 & & PGH1 & & (no prediction) & (no prediction) & (no prediction) \\
\hline $\begin{array}{l}\text { Moderate prob. } \\
\text { binding target }\end{array}$ & (no prediction) & & & ANDR,GCR & & (no prediction) & (no prediction) & (no prediction) \\
\hline Hepatotoxicity & NEG, $80 \%$ & POS, $53 \%$ & NEG, $86 \%$ & NEG, $82 \%$ & NEG, $80 \%$ & NEG, $69 \%$ & NEG, $79 \%$ & NEG, $79 \%$ \\
\hline Carcinogenicity & NEG, $84 \%$ & NEG, $66 \%$ & NEG, $70 \%$ & NEG, $74 \%$ & NEG, $70 \%$ & POS, $64 \%$ & NEG, $79 \%$ & NEG, $79 \%$ \\
\hline Immunotoxicity & POS, $84 \%$ & NEG, $97 \%$ & NEG, $95 \%$ & POS, $60 \%$ & POS, $54 \%$ & NEG, $72 \%$ & POS, $99 \%$ & POS, $99 \%$ \\
\hline Mutagenicity & NEG, $75 \%$ & NEG, $94 \%$ & NEG, $65 \%$ & NEG, $93 \%$ & NEG, $95 \%$ & NEG, $53 \%$ & NEG, $78 \%$ & NEG, $78 \%$ \\
\hline Cytotoxicity & NEG, $69 \%$ & NEG, $80 \%$ & NEG, $68 \%$ & NEG, $81 \%$ & NEG, $75 \%$ & NEG, $98 \%$ & NEG, $68 \%$ & NEG, $68 \%$ \\
\hline
\end{tabular}


Table 7: ADME-Tox predictions for black pepper secondary metabolite compounds. Key: AOFA = amine oxidase A. Organ toxicity predictions POS for positive and NEG for negative are reported with the corresponding prediction accuracy.

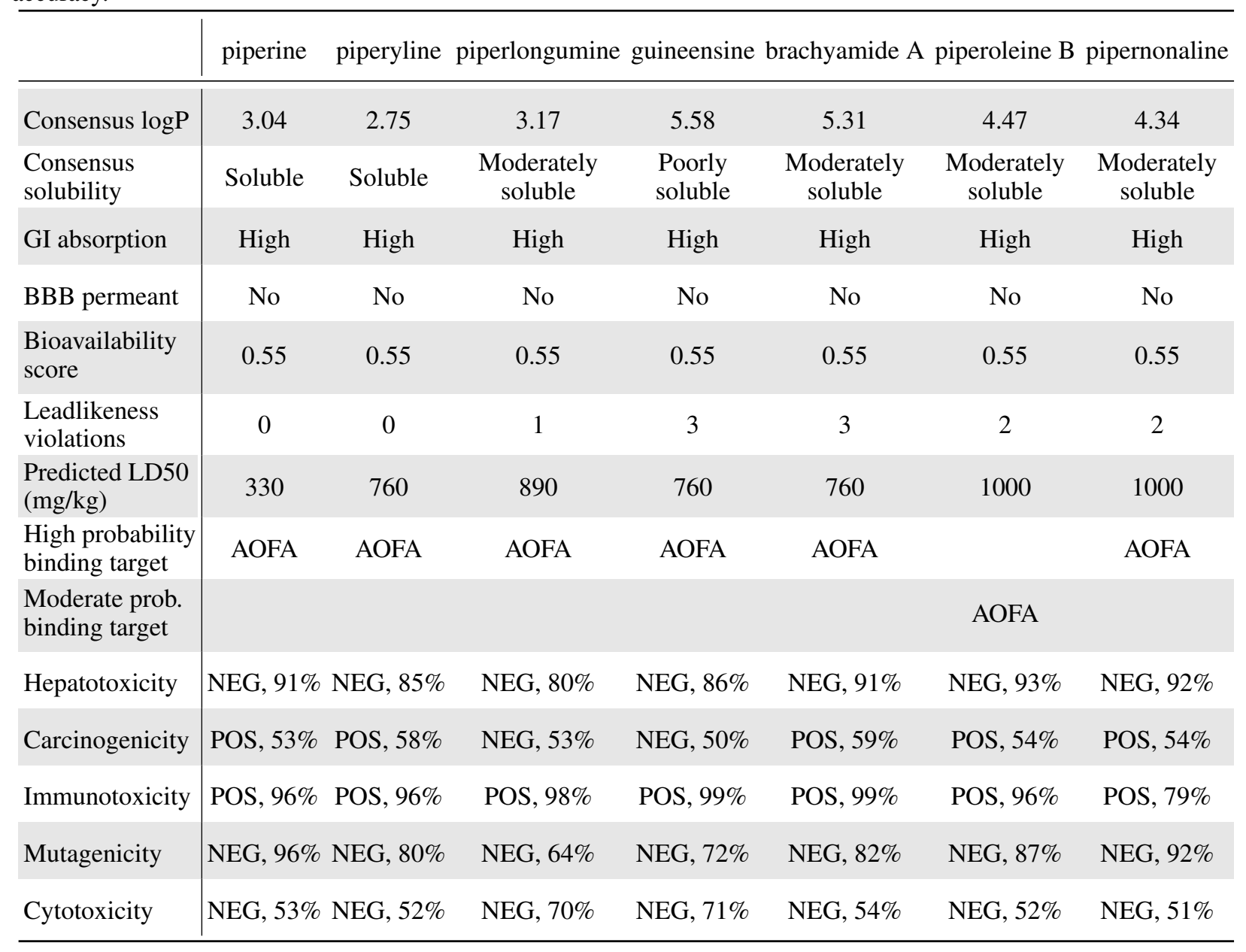


A PREPRINT - AUgust 26, 2020

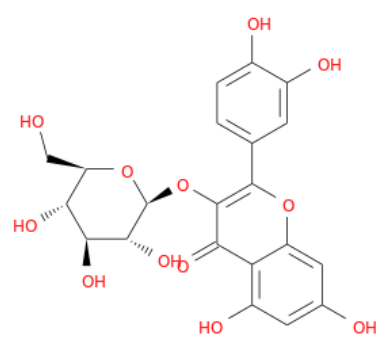

isoquercetin $\mathrm{MW}=464.10 \mathrm{~g} / \mathrm{mol} ; \mathrm{TDOF}=4$

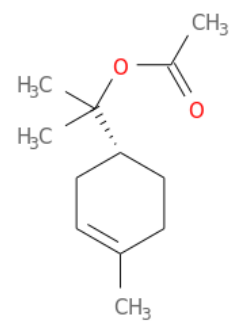

terpinyl acetate $\mathrm{MW}=196.29 \mathrm{~g} / \mathrm{mol} ; \mathrm{TDOF}=3$

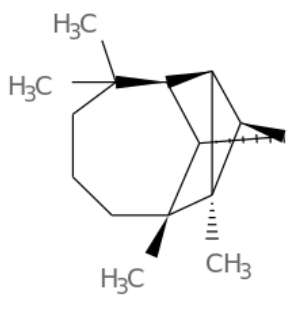

longicyclene $\mathrm{MW}=204.35 \mathrm{~g} / \mathrm{mol} ; \mathrm{TDOF}=0$

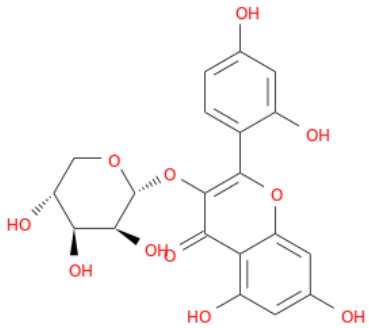

morin-3-O-lyxoside $\mathrm{MW}=434.35 \mathrm{~g} / \mathrm{mol} ; \mathrm{TDOF}=3$

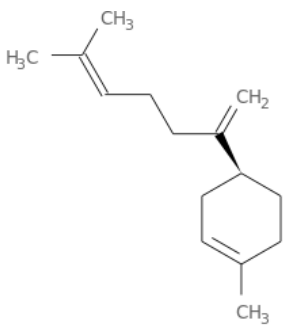

$\beta$-bisabolene $\mathrm{MW}=204.35 \mathrm{~g} / \mathrm{mol} ; \mathrm{TDOF}=4$

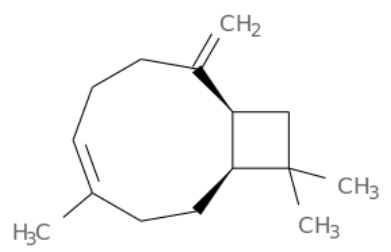<smiles>O=c1c(O)c(-c2ccc(O)cc2O)oc2cc(O)cc(O)c12</smiles>

morin

$M W=302.23 \mathrm{~g} / \mathrm{mol} ; \mathrm{TDOF}=1$

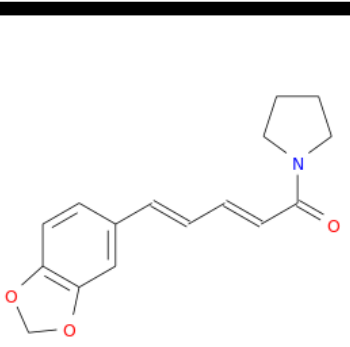

piperyline

$M W=271.31 \mathrm{~g} / \mathrm{mol} ;$ TDOF $=3$

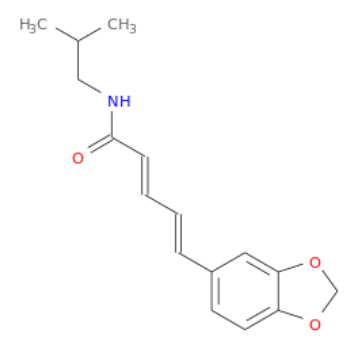

piperlongumine $\mathrm{MW}=317.34 \mathrm{~g} / \mathrm{mol} ; \mathrm{TDOF}=5 \quad \mathrm{MW}=383.53 \mathrm{~g} / \mathrm{mol} ; \mathrm{TDOF}=12$

piperine
$M W=285.34 \mathrm{~g} / \mathrm{mol} ; \mathrm{TDOF}=3$

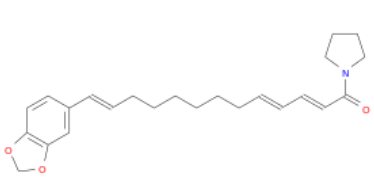

brachyamide $A$ $\mathrm{MW}=381.51 \mathrm{~g} / \mathrm{mol} ; \mathrm{TDOF}=10$

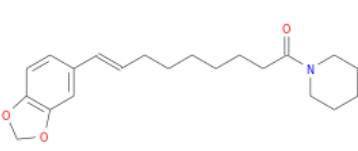

piperoleine $\mathrm{B}$ $\mathrm{MW}=343.50 \mathrm{~g} / \mathrm{mol} ; \mathrm{TDOF}=8$

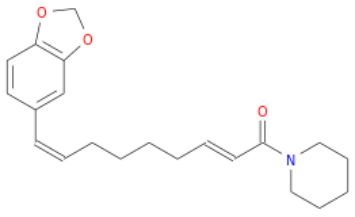

pipernonaline $\mathrm{MW}=341.40 \mathrm{~g} / \mathrm{mol} ; \mathrm{TDOF}=7$

Figure 1: Screened secondary metabolites secondary metaboliteed from P.guajava (top) and P. nigrum L. (bottom). The molecular weight and torsional degrees of freedom for each molecule are shown below their respective structure. 


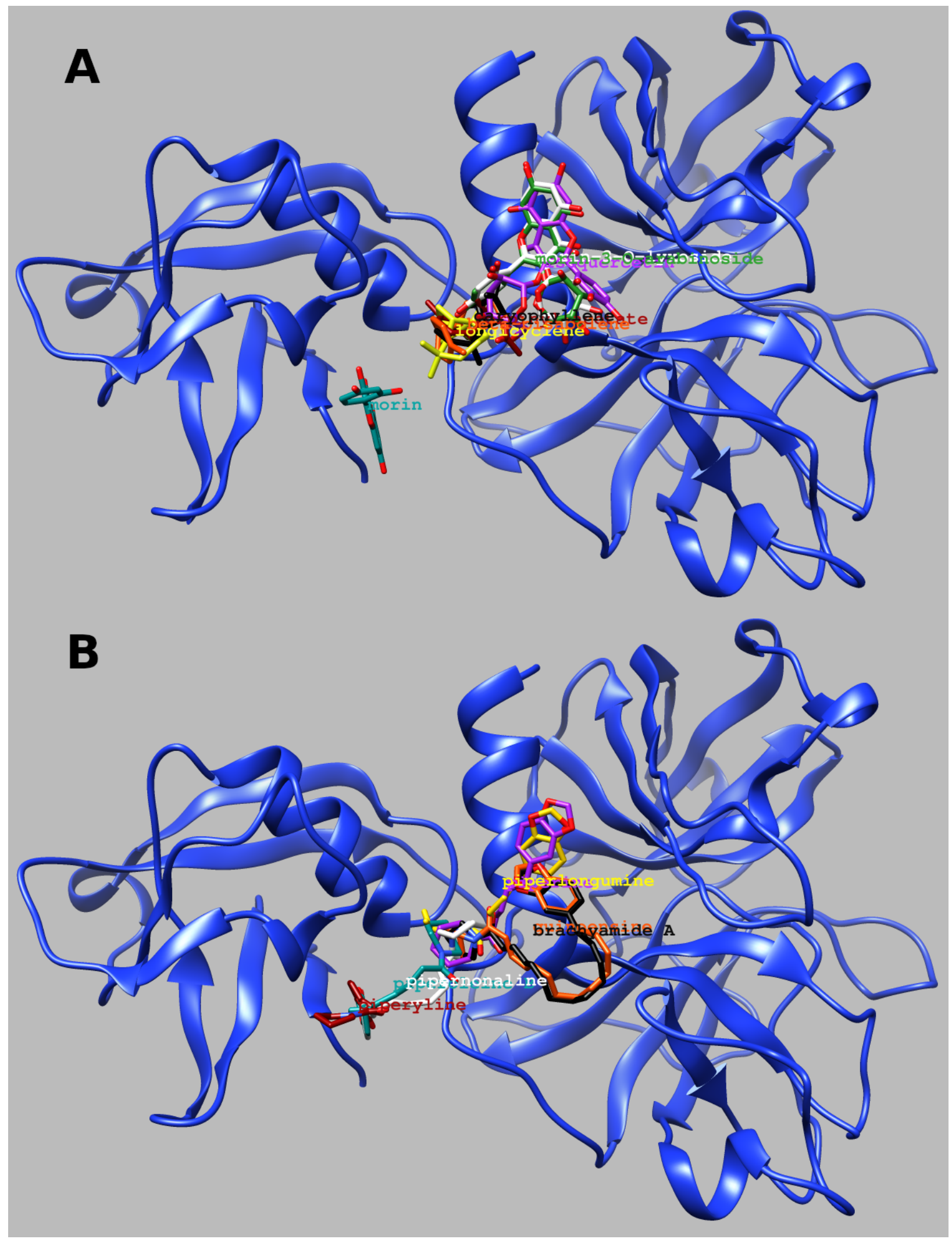

Figure 2: Docking to TMPRSS2 (homology model O15393) of (a) P. guajava L. and (b) P. nigrum L. secondary metabolites. 


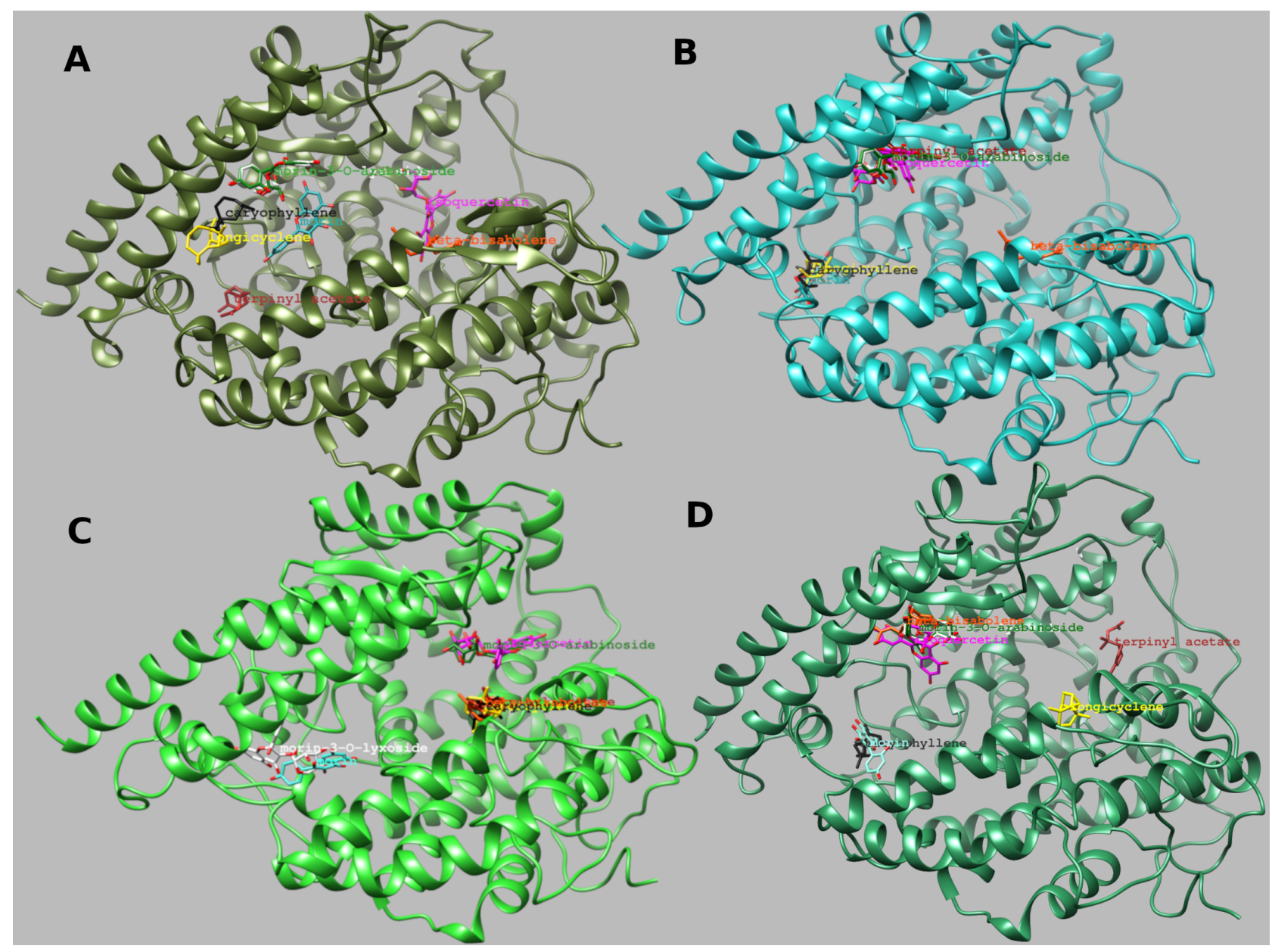

Figure 3: Binding poses of P. guajava L. secondary metabolites against the ACE2 models (A: 2AJF.A, B: 3SCI.A, C: 6ACK.D, and D: 6M17.B). 


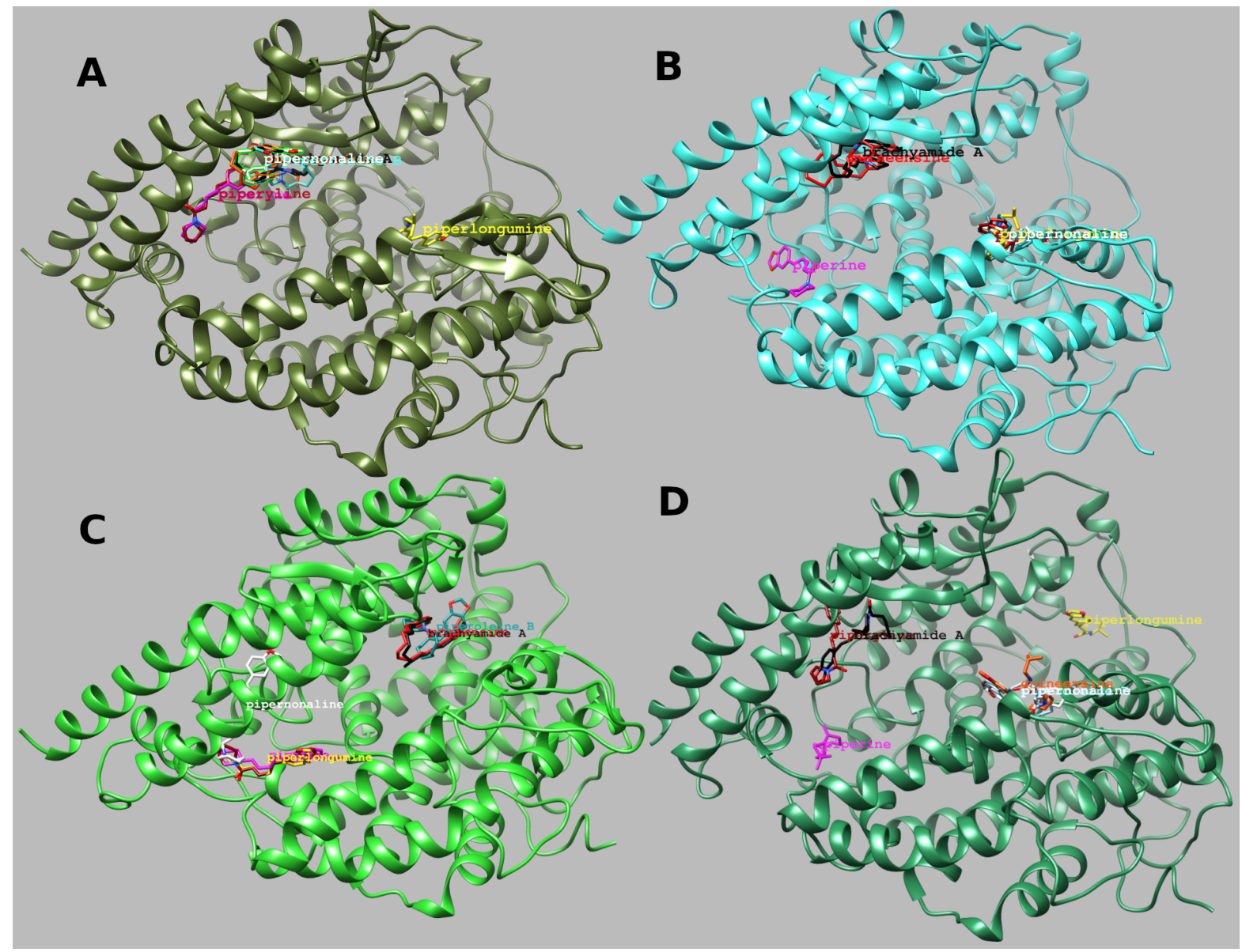

Figure 4: Binding poses of P. nigrum L. secondary metabolites against the ACE2 models (A: 2AJF.A, B: 3SCI.A, C: 6ACK.D, and D: 6M17.B). 


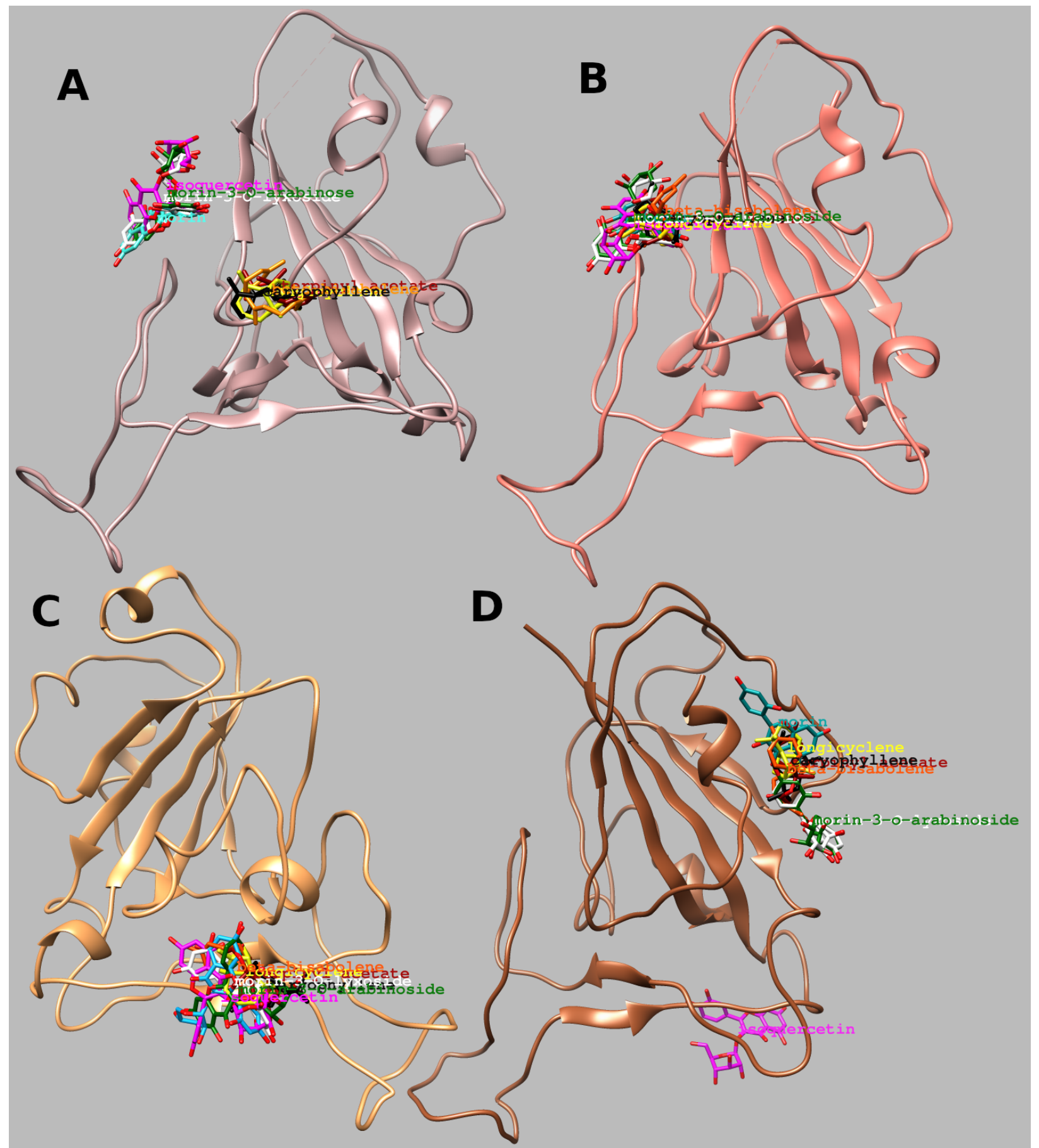

Figure 5: Binding poses of P. guajava L. secondary metabolites against the spike protein models (A: 2AJF.E, B: 3SCI.E, C: 6ACK.A, and D: 6M17.E). 


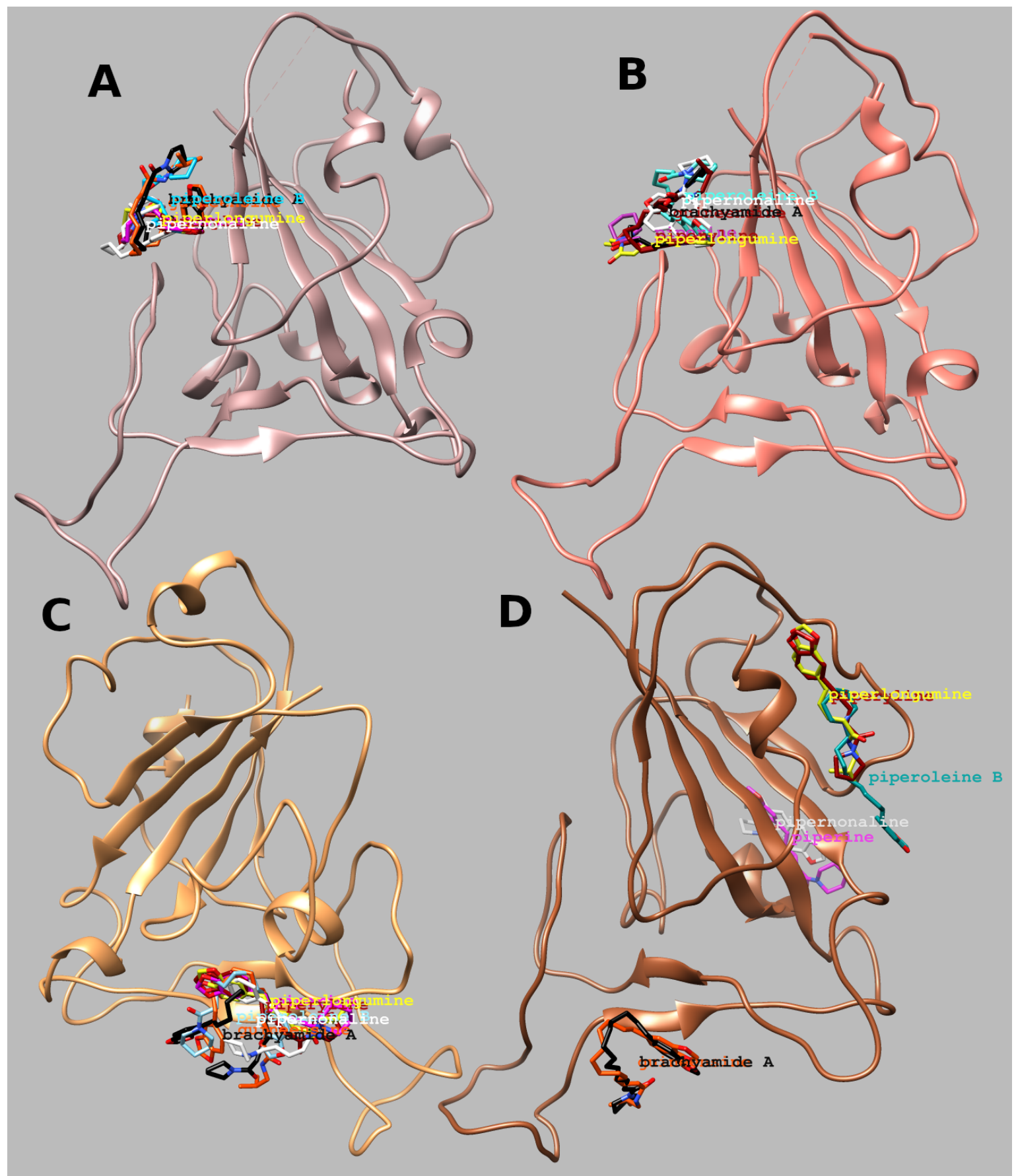

Figure 6: Binding poses of P. nigrum L. secondary metabolites against the spike protein models (A: 2AJF.E, B: 3SCI.E, C: 6ACK.A, and D: 6M17.E). 


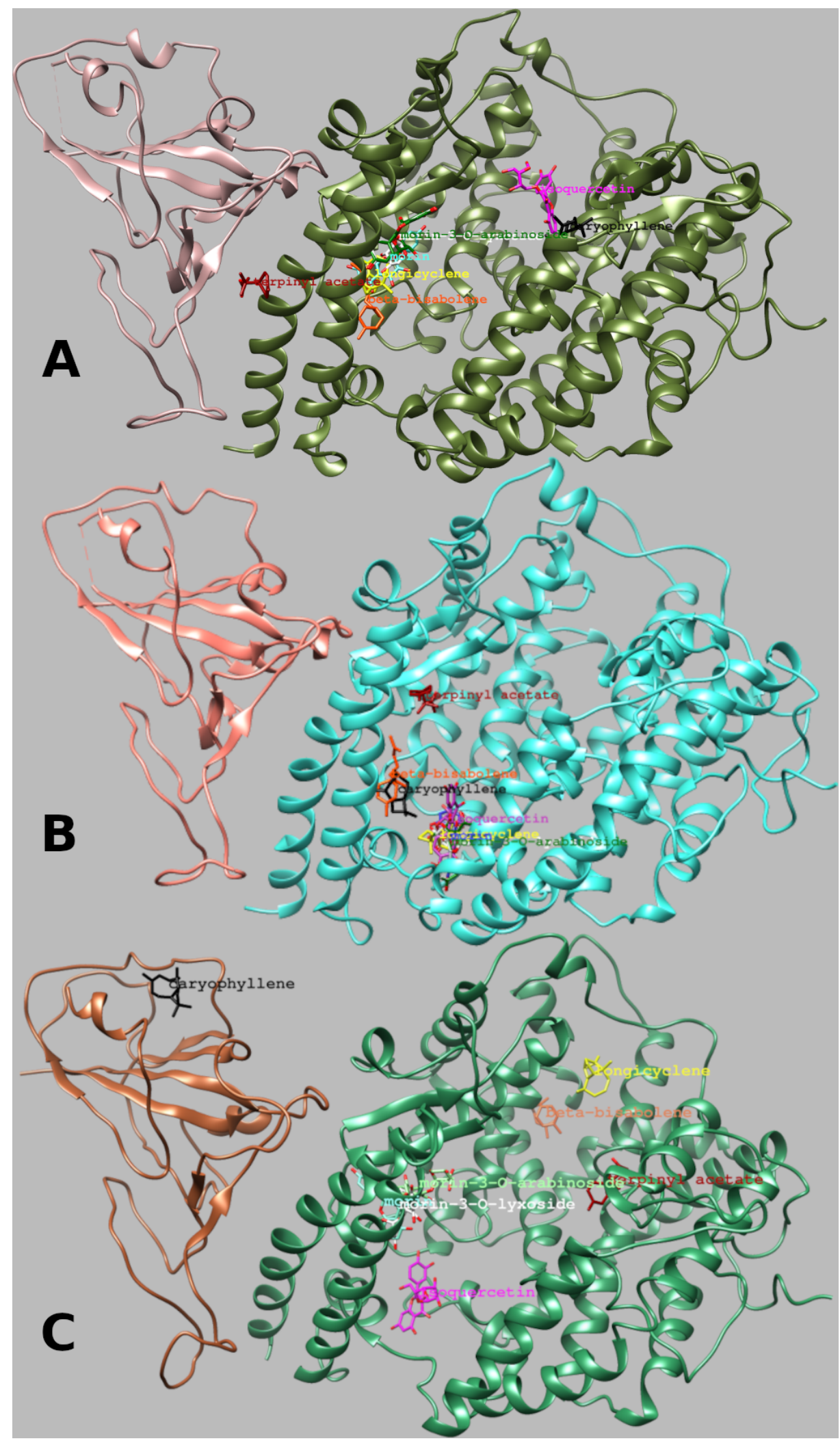

Figure 7: Binding poses of $P$. guajava L. secondary metabolites against the ACE2-Spike protein RBD complex models (A: 2AJF.AE, B: 3SCI.AE, and C: 6M17.BE). 


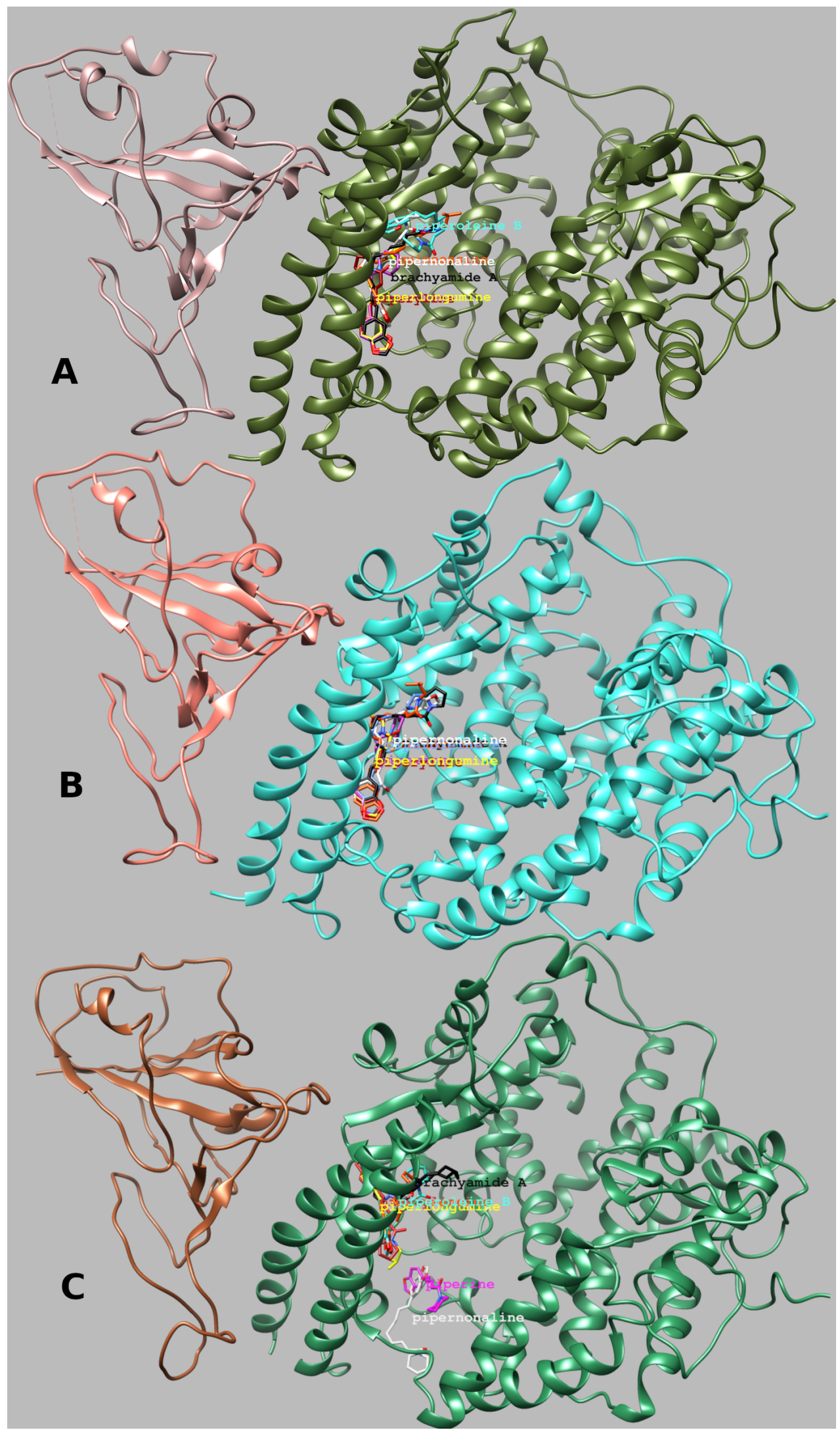

Figure 8: Binding poses of P. nigrum L. secondary metabolites against the ACE2-Spike protein RBD complex models (A: 2AJF.AE, B: 3SCI.AE, and C: 6M17.BE). 